\title{
Comparison of open and laparoscopic gastrectomy for gastric cancer: a low volume center experience
}

\author{
Adem Yüksel $^{1}$ (D), Murat Coşkun² (D), Hamdi Taner Turgut ${ }^{2}$ (D), Fatih Sümer ${ }^{3}$ (D) \\ ${ }^{1}$ Clinic of Gastroenterological Surgery, Kocaeli Derince Training and Research Hospital, Kocaeli, Turkey \\ ${ }^{2}$ Clinic of General Surgery, Kocaeli Derince Training and Research Hospital, Kocaeli, Turkey \\ ${ }^{3}$ Department of Gastroenterological Surgery, Inonu University School of Medicine, Malatya, Turkey
}

\begin{abstract}
Objective: In gastric cancer, laparoscopic gastrectomy is commonly performed in Asian countries. In other regions where tumor incidence is relatively low and patient characteristics are different, developments in this issue have been limited. In this study, we aimed to compare the early results for patients who underwent open or laparoscopic gastrectomy for gastric cancer in a low volume center.

Material and Methods: We retrospectively analyzed the data of patients who underwent curative gastric resection (open gastrectomy n: 30 ; laparoscopic gastrectomy $\mathrm{n}: 30$ ) by the same surgical team between 2014 and 2019.

Results: The tumor was localized in 60\% (36/60) of the patients in the proximal and middle 1/3 stomach. In laparoscopic gastrectomy group, the operation time was significantly longer (median, 297.5 vs 180 minutes; $p<0.05$ ). In open gastrectomy group, intraoperative blood loss (median 50 vs 150 ml; $<<0.05$ ) was significantly higher. Tumor negative surgical margin was achieved in all cases. Although the mean number of lymph nodes harvested in laparoscopic gastrectomy group was higher than the open surgery group, the difference was not statistically significant $(28.2 \pm 11.48$ vs $25.8 \pm 9.78$, respectively; $p=$ 0.394). The rate of major complications (Clavien-Dindo $\geq$ grade 3 ) was less common in the laparoscopic group (6.7\% vs $16.7 \% ; p=0.642)$. Mortality was observed in four patients ( 2 patients open, 2 patients laparoscopic).
\end{abstract}

Conclusion: In low-volume centers with advanced laparoscopic surgery experience, laparoscopic gastrectomy for gastric cancer can be performed with the risk of morbidity-mortality similar to open gastrectomy.

Keywords: Gastric cancer, laparoscopic gastrectomy, open gastrectomy, complication

Cite this article as: Yüksel A, Coșkun M, Turgut HT, Sümer F. Comparison of open and laparoscopic gastrectomy for gastric cancer: a low volume center experience. Turk J Surg 2021; 37 (1): 33-40

\section{Corresponding Author}

Adem Yüksel

E-mail: drademyuksel@gmail.com

Received: 11.09 .2020

Accepted: 12.01 .202

Available Online Date: 22.03.202

() Copyright 2021 by Turkish Surgical Society Available online at www.turkjsurg.com

DOI: $10.47717 /$ turkjsurg.2021.5048

\section{INTRODUCTION}

Gastric cancer is one of the most common cancers in the world. Although its incidence has decreased today, it is still the third most common cause of cancer-related deaths (1). The only potential curative treatment option in gastric cancer is gastrectomy with lymph node dissection (2). Laparotomy, which is the classical approach, carries serious risks for morbidity, mortality and impaired quality of life $(3,4)$. Therefore, techniques that can reduce these potential disadvantages and risks of the classical approach attract the attention of surgeons in the treatment of gastric cancer.

Laparoscopic gastrectomy was first reported in 1994 by Kitano et al. (5). Since then, laparoscopic gastrectomy has continued to be performed increasingly all over the world, mainly in Asian countries. The effectiveness, feasibility and oncological adequacy of the technique have been demonstrated in various studies (6-8). The majority of these studies are from Asian countries where tumor incidence is high, the tumor is diagnosed at an early stage and a young age with screening programs and cancer surgery is performed in specialized centers (6-8). The experience of laparoscopic gastrectomy is limited in European countries where tumor epidemiology and patient characteristics are different $(9,10)$.

Geographically, Turkey is the crossroads of Europe and Asia. Parallel to that, the incidence of gastric cancer, tumor and patient characteristics are also somewhat between the European and Asian communities (11). In addition, gastric cancer surgery is also performed outside of specialized centers in our country. This situation, together with the relatively low tumor incidence, leads to low patient volume in a single center. 
In this study, it was aimed to compare the early results of patients who underwent open or laparoscopic gastrectomy (total, subtotal) for gastric cancer in our clinic and the oncological adequacy of both techniques.

\section{MATERIAL and METHODS}

After approval of the Institutional Ethics Board Committee, the data of patients who were operated consecutively for gastric cancer between January 2014 and December 2019 were collected retrospectively. The diagnosis was made by upper gastrointestinal endoscopy and endoscopic biopsy. Clinical staging was done by using contrast computed tomography (CT). Positron emission tomography (PET) was used in patients with suspected metastasis. Patients with ASA score $>3$ and the patients who were operated on by different surgical teams for palliative resection were excluded from the study. Between these dates, 60 patients who underwent curative gastrectomy were included in the study. Until January 2016, open gastrectomy (Open gastrectomy group; n: 30) was performed in all patients and patients whose adjacent organ invasion (cT4b) was shown in preoperative radiological examinations. Laparoscopic gastrectomy (Laparoscopic gastrectomy group; n: 30) was applied to other potential curative patients other than these criteria.

The patients were hospitalized 24 hours before the operation. Deep venous thrombosis prophylaxis (dalteparin sodium 35 IU/ $\mathrm{kg}$ ) was started. Before anesthesia induction, all patients received prophylaxis with 2 grams of first-generation cephalosporin.

\section{Surgery}

D1+ lymph node dissection was performed in patients with age $\geq 70$ and comorbid disease, regardless of surgical technique and tumor stage. D2 lymphadenectomy was performed in other patients. Lymph node dissection was performed according to the Japanese gastric cancer treatment guidelines (2).

\section{Laparoscopic Gastrectomy}

The operations (total, subtotal) were performed in a French position with five trocars. The surgical team, equipment and the location of the trocars are shown in Figure 1. A total omentectomy was performed in all cases. However, bursectomy was not performed. Lymph node dissection and total omentectomy were performed according to the following stages. The gastrocolic ligament was opened by omentectomy. In the corner of the spleen, left gastroepiploic vessels were dissected (no 4b). Right gastroepiploic vessels (no 4d) and infrapyloric lymph nodes (no 6) were dissected. Gastroduodenal artery was followed in the posterior of the duodenum, and its junction with the hepatic artery was identified. Meanwhile, a window was created for transection in the supraduodenal area. The duodenum was transected with laparoscopic $60 \mathrm{~mm}$ linear stapler. Supraduodenal lymph nodes (no.5) were dissected. Right gastric artery was ligated. Targeted lymph node dissection (D1+, D2) according to tumor localization

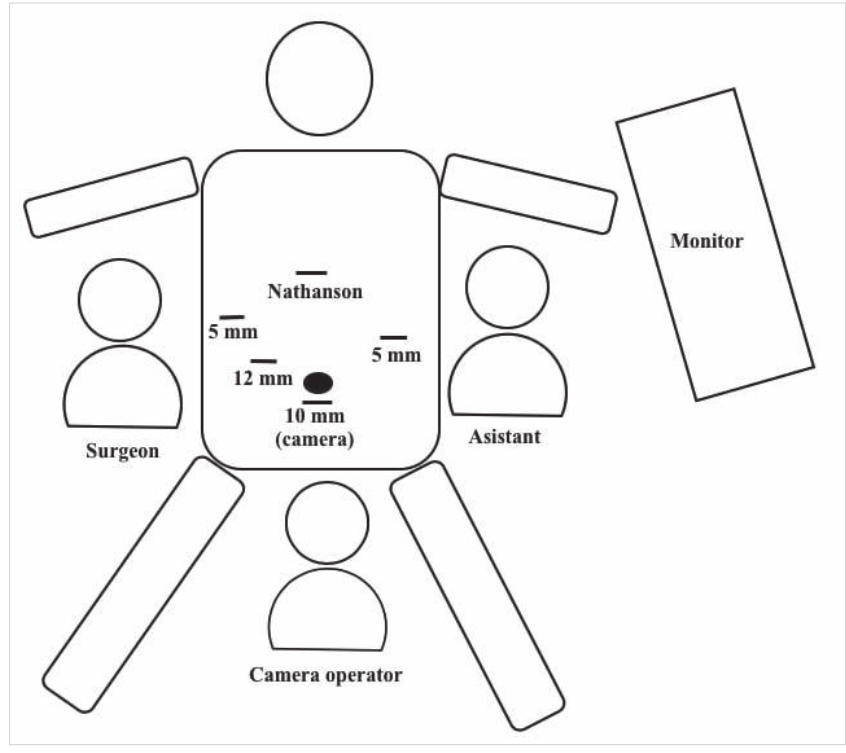

Figure 1. Patient position, placement of equipment and trocars for laparoscopic gastrectomy.

and other factors (age, comorbid status, etc.) was completed as recommended in the Japanese gastric cancer treatment guidelines (2). Dissections were performed with a harmonic scalpel. Intraoperative gastroscopy was performed in all cases in order to determine the surgical margin. All reconstructions were antecolic Roux-en-Y type. In subtotal gastrectomy, standard gastrojejunostomy was performed with a $60 \mathrm{~mm}$ endo stapler from the posterior of the remnant stomach. Stapler spaces were closed in double-layers with continuous sutures of $3 / 0$ prolene. Jejunojejunostomy anastomosis was performed with a $60 \mathrm{~mm}$ endo stapler at $50 \mathrm{~cm}$ distal. Stapler space was closed in double-layers with $3 / 0$ prolene. The specimen was extracted through a suprapubic mini transverse incision. Esophagojejunostomy anastomosis in total gastrectomy was achieved with three different techniques. These were transorally inserted anvil (OrVilTM; Covidien, Mansfield, MA, USA), side-to-side with a linear stapler and transperitoneal double stapler techniques. The specimen was extracted through a suprapubic mini transverse incision in patients who underwent anastomosis with linear stapler, and from the mini-incision in the upper left quadrant where circular stapler were placed in other patients. In all patients, a drain was placed in the abdomen.

\section{Open Gastrectomy}

The operations were performed with a midline incision extending under the umbilicus in supine position. Total omentectomy was performed in all patients, but bursectomy was performed in patients who underwent D2 lymph node dissection. Lymph node dissection was performed as in laparoscopic surgery. Reconstruction was performed as retro colic Roux-en-Y or Billroth-ll according to the surgeon's preference in subtotal gastrectomy, and Rouxen-Y in total gastrectomy. Gastrojejunostomy was performed with 
a linear stapler and esophagojejunostomy with a circular stapler. In the patients who underwent subtotal gastrectomy, one drain was placed in the abdomen, and in the patients who underwent total gastrectomy, two drains were placed.

\section{Postoperative Follow-up}

In the laparoscopic group, nasogastric catheter was not used. On the other hand, a nasogastric catheter was used in the open surgery group and was often removed on the $1^{\text {st }}$ or $2^{\text {nd }}$ postoperative day after the first gas discharge. All patients were evaluated by routine laboratory tests (hemogram, biochemistry, CRP) on the $1^{\text {st }}, 3^{\text {rd }}$, and $5^{\text {th }}$ days. In patients for whom intraabdominal pathology was not considered according to clinical findings (physical examination, laboratory) and aspirate from the abdominal drain, oral food was started on the postoperative $3^{\text {rd }}$ day for those who underwent subtotal gastrectomy in the laparoscopic group, postoperative $5^{\text {th }}$ day for those who underwent total gastrectomy, and on the postoperative $4^{\text {th }}$ day for those who underwent subtotal gastrectomy in the laparotomy group, and on the postoperative $5^{\text {th }}$ day for those who underwent total gastrectomy. Patients who had adequate oral intake and no clinical problems were discharged.

Age, sex, body mass index (BMI), previous abdominal surgery status, comorbid diseases, American Society of Anesthesiologists (ASA) score, neoadjuvant therapy status, surgical technique (open, laparoscopic), tumor localization, gastrectomy type (total, subtotal), lymph node dissection type, operative data (operation time, blood loss), morbidity mortality and histopathological examination results of the specimen were recorded for the patients. Complications were grouped according to the Clavien-Dindo Classifi- cation (12). Tumor staging was performed according to AJCC $8^{\text {th }}$ Edition (13).

\section{Statistical Analysis}

Statistical evaluation was performed with IBM SPSS 20.0 (IBM Corp., Armonk, NY, USA) program package. Compatibility with normal distribution was assessed by the Shapiro-Wilk test. Numerical variables with normal distribution were expressed as mean +/- standard deviation while numerical variables without normal distribution were expressed as median (Interquartile range (IQR); $25^{\text {th }}$ percentile- $75^{\text {th }}$ percentile), and categorical variables were given as frequency (percent). The difference among the groups was determined by the independent-samples t-test for the numerical variables with normal distribution, whereas it was determined with the Mann-Whitney $U$ test for the numerical variables without normal distribution. Correlations between categorical variables were analyzed by the Chi-squared test or Fisher s exact test as appropriate. For a two-tailed hypothesis test, $\mathrm{p}<0.05$ was considered sufficient for statistical significance.

\section{RESULTS}

\section{Patient Characteristics}

Sixty patients underwent gastrectomy with curative intent (30 open/30 laparoscopic). Thirty-eight patients were (63.3\%) males and 22 (36.7\%) patients were females. Mean age of the patients was $63.1 \pm 11$ years. The frequency of male patients was higher in the open gastrectomy group ( $p=0.016$ ). In total, 8 patients ( 3 open, 5 laparoscopic) received neoadjuvant chemotherapy. There was no significant difference between the groups in terms of other factors related to patients. Patient characteristics are listed in Table 1.

Table 1. Patient demographics and clinical parameters

\begin{tabular}{|c|c|c|c|}
\hline Variables & Open (n: 30) & Laparoscopic (n: 30) & $p$ \\
\hline Age (year) & $63.83 \pm 11.60$ & $62.40 \pm 10.72$ & .621 \\
\hline $\mathrm{BMI}\left(\mathrm{kg} / \mathrm{m}^{2}\right)$ & $22.97 \pm 3.77$ & $24.51 \pm 4.21$ & .142 \\
\hline $\begin{array}{l}\text { Sex } \\
\text { Male } \\
\text { Female }\end{array}$ & $\begin{array}{c}24(80 \%) \\
6(20 \%)\end{array}$ & $\begin{array}{l}14(46.7 \%) \\
16(53.3 \%)\end{array}$ & .015 \\
\hline $\begin{array}{c}\text { ASA score } \\
\text { I } \\
\| \\
\text { III }\end{array}$ & $\begin{array}{l}4(13.3 \%) \\
12(40.0 \%) \\
14(46.7 \%)\end{array}$ & $\begin{array}{c}1(3.3 \%) \\
16(53.3 \%) \\
13(43.4 \%)\end{array}$ & .348 \\
\hline $\begin{array}{l}\text { Previous abdominal surgery } \\
\text { Yes } \\
\text { No }\end{array}$ & $\begin{array}{c}5(16.7 \%) \\
25(83.3 \%)\end{array}$ & $\begin{array}{c}1(3.3 \%) \\
29(96.7 \%)\end{array}$ & .195 \\
\hline $\begin{array}{l}\text { Neo-adjuvant chemotheraphy } \\
\text { Yes } \\
\text { No }\end{array}$ & $\begin{array}{c}3(10 \%) \\
27(90 \%)\end{array}$ & $\begin{array}{c}5(16.7 \%) \\
25(83.3 \%)\end{array}$ & .706 \\
\hline $\begin{array}{l}\text { Co-morbidity } \\
\quad=1 \\
>1 \\
\text { None }\end{array}$ & $\begin{array}{c}9(30.0 \%) \\
8(26.7 \%) \\
13(43.3 \%)\end{array}$ & $\begin{array}{c}9(30.0 \%) \\
11(36.7 \%) \\
10(33.35 \%)\end{array}$ & .651 \\
\hline
\end{tabular}




\section{Operative Outcomes and Complications}

The tumor was localized in proximal third in 46.7\% (28/60) of the cases, middle third in $13.3 \%$ (8/60), lower third in 36.7\% (22/60), and remnant stomach in $3.3 \%(2 / 60)$ of patients, respectively. Total gastrectomy was performed in $61.7 \%$ of the cases $(37 / 60)$ and subtotal gastrectomy in 38.3\% (23/60). D2 lymph node dissection was performed in $78.3 \%$ (47/60) of the cases, and D1+ in $21.7 \%$ (13/60). In the open surgery group, median operation time was 180 (IQR; 163.75 - 192.5) minutes, while in the laparoscopy group, it was 297.5 (IQR; 257.5-310) minutes. The operation time was statistically significantly shorter in the open surgery group ( $p<0.05)$. Median intraoperative blood loss was 150 (IQR 100-200) $\mathrm{ml}$ in open surgery and 50 (IQR; 50-100) $\mathrm{ml}$ in laparoscopy $(p<0.05)$. Tumor localization and operative data are listed in Table 2. In three (10\%) patients, the laparoscopic procedure was converted to open surgery in the laparoscopic gastrectomy group. The causes of conversion were the total occlusion of the efferent loop and in the end-to-side esophagojejunostomy anastomosis using transorally inserted anvil (Orvil), the injury of the splenic artery during dissection, and nonevaluation of the tumor invasion status laparoscopically. These patients were evaluated in the laparoscopic group.

Although the major complication ( $\geq$ grade 3 ) rate according to the Clavien-Dindo Classification was lower in the laparoscopic surgery group (6.7\%) compared to open surgery (16.7\%), there was no statistically significant difference between the groups $(p=0.642)$. In the open surgery group, $4(13.3 \%)$ cases were reoperated due to various postoperative complications (bleeding, anastomotic leak, evisceration, spleen ischemia). No patient was reoperated in the laparoscopic gastrectomy group. Anastomotic leak was observed in two patients (6.6\%) in the laparoscopic group. These patients were operated on after neo- adjuvant chemotherapy. Anastomotic leak was detected radiologically and treated with conservative methods. Anastomotic leak was detected in one patient (3.3\%) of the open surgery group. This patient was reoperated due to intra-abdominal sepsis. Mortality was observed in four patients (6.6\%) in total. In the open surgery group, mortality was observed in two patients reoperated for anastomotic leak and bleeding due to pancreatic fistula. In the laparoscopy group, mortality was observed in two patients, one who developed ischemic hepatitis due to postoperative portal vein thrombosis and one who developed myocardial infarction. There was no significant difference between the groups in terms of mortality $(p=0.100)$ (Table 3$)$.

\section{Histopathological Outcomes}

Median tumor diameter was $6(\mathrm{IQR} ; 3-7.5) \mathrm{cm}$ in the open surgery group and $4(\mathrm{IQR} ; 2.75-6) \mathrm{cm}$ in the laparoscopy group $(\mathrm{p}=$ 0.033). Tumor negative surgical margin (R0) was achieved in all cases. $18.3 \%(11 / 60)$ of the cases were evaluated as early-stage and $81.7 \%$ (49/60) were evaluated as advanced ( $\geq$ T2) gastric cancer. T4 tumor rate was higher in the open gastrectomy group (70\% vs 26.7\%; p: 0.003). Mean number of lymph nodes harvested was $25.8 \pm 9.78$ in the open surgery group, and 28.2 \pm 11.48 in the laparoscopic group. Although mean number of lymph nodes harvested in the laparoscopic gastrectomy group was high, the difference between the groups was not statistically significant ( $p=0.394)$ (Table 4).

\section{DISCUSSION}

Laparoscopic gastrectomy for gastric cancer is a difficult and complex procedure. In Asian studies, it has been indicated that the learning curve requires a serious number of cases (50-90 cases) and is a challenging process $(14,15)$. In our clinic, relatively few (15 patients per year) number of curative gastric re-

Table 2. Tumor localization and operative data in patients

\begin{tabular}{|c|c|c|c|}
\hline Variables & Open (n: 30) & Laparoscopic (n: 30) & $p$ \\
\hline $\begin{array}{l}\text { Tumor location } \\
\text { Proximal } 1 / 3 \\
\text { Middle } 1 / 3 \\
\text { Lower } 1 / 3 \\
\text { Remnant }\end{array}$ & $\begin{array}{c}15(50.0 \%) \\
3(10.0 \%) \\
11(36.7 \%) \\
1(3.3 \%)\end{array}$ & $\begin{array}{c}13(43.3 \%) \\
5(16.7 \%) \\
11(36.7 \%) \\
1(3.3 \%)\end{array}$ & .909 \\
\hline $\begin{array}{l}\text { Gastrectomy type } \\
\text { Total } \\
\text { Subtotal }\end{array}$ & $\begin{array}{l}19(63.3 \%) \\
11(36.7 \%)\end{array}$ & $\begin{array}{l}18(60 \%) \\
12(40 \%)\end{array}$ & 1.0 \\
\hline $\begin{array}{l}\text { Dissection type } \\
\text { D1+ } \\
\text { D2 }\end{array}$ & $\begin{array}{c}6(20.0 \%) \\
24(80.0 \%)\end{array}$ & $\begin{array}{c}7(21.7 \%) \\
23(78.3 \%)\end{array}$ & .794 \\
\hline $\begin{array}{l}\text { Reconstruction type } \\
\text { Roux-en Y } \\
\text { Billroth-II }\end{array}$ & $\begin{array}{c}26(86.7 \%) \\
4(13.3 \%)\end{array}$ & $\begin{array}{c}30(100 \%) \\
0(0 \%)\end{array}$ & .112 \\
\hline Operation time (min) & 180 (163.75-192.5) & $297.5(257.5-310)$ & $<0.05$ \\
\hline Blood loss (ml) & $150(100-200)$ & $50(50-100)$ & $<0.05$ \\
\hline
\end{tabular}




\begin{tabular}{|l|c|c|c|}
\hline Table 3. Peri-operative outcomes & Laparoscopic (n: 30) & p \\
\hline Variables & Open (n: 30) & $9(30.0 \%)$ & .589 \\
\hline $\begin{array}{c}\text { Postoperative Complication } \\
\text { Yes } \\
\text { No }\end{array}$ & $12(40.0 \%)$ & $21(70.0 \%)$ & .642 \\
\hline $\begin{array}{c}\text { Clavien Dindo } \\
\quad \text { Grade 3 } \\
\geq \text { Grade 3 }\end{array}$ & $18(60.0 \%)$ & $7(23.3 \%)$ & .112 \\
\hline Re-operation & $7(23.3 \%)$ & $2(6.7 \%)$ & 1.00 \\
\hline Mortality & $5(16.7 \%)$ & $0(0 \%)$ & \\
\hline
\end{tabular}

Table 4. Pathological outcomes

\begin{tabular}{|c|c|c|c|}
\hline Variables & Open (n: 30) & Laparoscopic (n: 30) & $\mathrm{p}$ \\
\hline Tumor size (cm) & $6(3-7.5)$ & $4(2.75-6)$ & .033 \\
\hline $\begin{array}{l}\text { Tumor differentiation } \\
\text { Poor/Undifferentiated } \\
\text { Moderate } \\
\text { Well }\end{array}$ & $\begin{array}{c}13(43.3 \%) \\
12(40.0 \%) \\
5(16.7 \%)\end{array}$ & $\begin{array}{l}15(50 \%) \\
11(36.6 \%) \\
4(13.4 \%)\end{array}$ & .100 \\
\hline $\begin{array}{c}\text { Tstage } \\
\text { T1 } \\
\text { T2 } \\
\text { T3 } \\
\text { T4 }\end{array}$ & $\begin{array}{l}5(16.7 \%) \\
2(6.7 \%) \\
2(6.7 \%) \\
21(70 \%)\end{array}$ & $\begin{array}{l}6(20 \%) \\
4(13.3 \%) \\
12(40 \%) \\
8(26.7 \%)\end{array}$ & .003 \\
\hline Number of harvested LN & $25.8 \pm 9.78$ & $28.2 \pm 11.48$ & .394 \\
\hline $\begin{array}{c}\text { N stage } \\
\text { N0 } \\
\text { N1 } \\
\text { N2 } \\
\text { N3 }\end{array}$ & $\begin{array}{c}6(20.0 \%) \\
7(23.3 \%) \\
8(26.7 \%) \\
9(30 \%)\end{array}$ & $\begin{array}{c}14(46.7 \%) \\
3(10.0 \%) \\
3(10.0 \%) \\
10(33.3 \%)\end{array}$ & .068 \\
\hline $\begin{array}{l}\text { Tumor stage (AJCC } 8^{\text {th }} \text { Edition TNM) } \\
\text { Stage } 1 \\
\text { Stage } 2 \\
\text { Stage } 3\end{array}$ & $\begin{array}{c}4(13.3 \%) \\
7(23.3 \%) \\
19(63.4 \%)\end{array}$ & $\begin{array}{c}9(30.0 \%) \\
8(26.7 \%) \\
13(43.3 \%)\end{array}$ & .211 \\
\hline
\end{tabular}

sections are performed compared to Asian countries. In addition, unlike Asian countries, the majority of cases diagnosed in our clinic were found to have advanced gastric cancer $(81.7 \%)$ predominantly located in the middle-proximal stomach. In our study comparing this group of patients, in LG, although the duration of surgery was longer, intraoperative blood loss was less.

Regardless of the tumor stage (early, advanced), the duration of surgery in LG was longer in most of the studies comparing open and laparoscopic gastrectomy $(7,16,17)$. A standard total omentectomy was performed in our study. The duration of omentectomy was not recorded separately. However, it was observed that omentectomy significantly extended the operation time, especially in laparoscopic surgery. The reason for this may be the location of the omentum in a wide area on the transverse axis in the abdomen, and fixed placement of trocars and devices in laparoscopy. In studies reported in countries where laparoscopic gastrectomy is more commonly performed, the mean duration of operation has been reported as 258-278 minutes $(16,17)$. In these studies, omentectomy was not applied as standard, and extracorporeal reconstruction was performed $(16,17)$. In our study, the mean duration for operation in the laparoscopic group was 283 minutes. Total omentectomy and intracorporeal reconstruction were performed in all cases. Considering these results, it was observed that the operation time was similar to the clinics where laparoscopic gastrectomy was commonly performed.

Randomized controlled studies and meta-analysises have shown that laparoscopic and open gastrectomy was performed with similar morbidity and mortality rates $(7,8,18)$. In our study, no significant difference was found between the two techniques in terms of morbidity and mortality. In studies, morbidity and mortality rates show geographical differences. Morbidity and mortality rates reported in Asian studies are relatively low compared to European studies (19). In our study, it was deter- 
mined that the rate of major complications (Clavien Dindo $\geq$ 3) especially in laparoscopic gastrectomy was similar to that of Asian studies $(6,7)$. In our study, mortality rate was found to be quite higher than these studies. The predominantly advanced stage and proximal location of the tumor may be the reason for this result. Mortality rates in studies of European countries (10) with tumor characteristics similar to our patient group were similar to our results. Howewer, in the open gastrectomy group, the fact that there were more male patients and patients with $\mathrm{T} 4$ tumors, and having had bursectomy and the fact thatsurgical technique (anastomosis technique, etc.) could not be standardized, especially in laparoscopic total gastrectomy, may have affected the morbidity and mortality rates. This should be taken into account when evaluating the results.

The rate of conversion to open surgery can vary geographically, just like morbidity and mortality rates. While the rate of conversion to open surgery has been reported to be between $6.4 \%$ to $6.6 \%$ in Asian studies $(7,15)$, this rate has been reported as $18 \%$ in a European study (9). In our study, the conversion rate to open surgery was $10 \%$. This rate seems to be acceptable when the learning curve and the limited number of cases are considered.

The $\mathrm{RO}$ resection rate and the number of lymph nodes harvested are important indicators in determining surgical quality. When the two techniques were compared in terms of surgical quality, these parameters were similar in the two groups. The absence of tactile sensation in laparoscopic surgery may cause difficulties in determining tumor localization and surgical margins. Tumor positive surgical margin rate in minimally invasive gastrectomy has been reported to be $6.9-7.5 \%(9,10)$. In our study, tumor localization and surgical margins were determined by performing routine intraoperative gastroscopy in the laparoscopic group. This approach may be the main factor in achieving tumor negative surgical margin in all cases.

The width of lymph node dissection is a debated subject. D2 lymphadenectomy is the standard approach in >T1 tumors in Asia and has been shown to provide a survival advantage over D1 lymphadenectomy (20). In our clinic, the general approach is to perform D2 lymphadenectomy in all cases due to the inability to distinguish early gastric cancer in the preoperative period and the fact that the majority of cases are advanced gastric cancer. However, considering the high morbidity and mortality rates reported in cases with D2 lymphadenectomy in European studies $(21,22)$, D1 + lymphadenectomy was preferred in selected cases of elderly age ( $\geq 70$ years) with severe comorbid disease. The Italian Research Group for Gastric Cancer treatment guideline (23) likewise recommends D1 or D1+ lymph node dissection in selected cases (high-risk patients) where D2 lymph node dissection cannot be performed. A minimum of 15 lymph nodes are recommended to be harvested for correct staging and prognostic evaluation in gastric cancer (24). In our study, an average of 28 lymph nodes were harvested in LG and 25 in open gastrectomy. These results show the adequacy of lymph node dissection. Contrary to studies $(25,26)$ reporting that fewer lymph nodes are harvested in laparoscopy, in our study, more lymph nodes were harvested in LG. The fact that a larger field of view in laparoscopy enables careful and detailed dissection may explain this difference.

Reconstruction in laparoscopic gastrectomy is one of the most difficult stages of the procedure. Unlike Asian countries, in the West, complex laparoscopic bariatric procedures are widely applied (27). These procedures provide an important experience, especially with regard to intracorporeal gastrojejunostomy anastomosis. With such experience, reconstruction was performed easily and safely in laparoscopic subtotal gastrectomy in our clinic. However, esophagojejunostomy anastomosis is a difficult and complex procedure. Many different techniques for laparoscopic esophagojejunostomy have been described in the literature (28). In our clinic, this type of anastomosis has not been standardized yet. Esophagojejunostomy was achieved with three different techniques in our study. In clinics like ours with a limited number of cases and still on the learning curve, the complexity and difficulty of this type of anastomosis should be taken into consideration.

Our results demonstrate the technical feasibility of laparoscopic gastrectomy for gastric cancer in low volume centers with advanced laparoscopic experience. However, in our study, lack of data of survival rates led to continued concerns about oncological adequacy. One of the important limitations of our study is the bias in patient selection. There are few studies in the literature regarding laparoscopic gastrectomy in adjacent organ invasive tumors (T4b) (29). This is because; disruption of normal anatomy due to invasion and abnormal neovascularization may make the laparoscopic approach difficult (30). We prefer open surgery in these patients because of the fact that we are on the learning curve and laparoscopic approach is more complex in these tumors. This is the main cause of bias in our study. In addition, the small number of patients, being a retrospective study, and the lack of data on postoperative recovery profile (pain score, quality of life, etc.) are other factors of limitation of our study.

\section{CONCLUSION}

According to the results of this study in which patients with advanced gastric cancer were operated on, laparoscopic gastrectomy for gastric cancer can be performed in low volume centers if the team is experienced in advanced laparoscopy because it does not increase surgical morbidity. 
Ethics Committee Approval: The approval for this study was obtained from Healt Sciences University Kocaeli Derince Training and Research Hospital Clinical Research Ethics Committee (Decision no: 2019-98 Date: 14.11.2019).

Peer-review: Externally peer-reviewed.

Author Contributions: Concept - A.Y., M.C.; Design - A.Y., H.T.T., M.C.; Supervision - F.S.; Data Collection and/or Processing - A.Y., M.C.; Analysis and Interpretation - A.Y., H.T.T.; Literature Review - A.Y., F.S., H.T.T.; Writing Manuscript - A.Y.; Critical Reviews - A.Y., F.S.

Conflict of Interest: The authors declare that they have no conflict of interest.

Financial Disclosure: The authors declared that this study has received no financial support.

\section{REFERENCES}

1. Bray F, Ferlay J, Soerjomataram I, Siegel RL, Torre LA, Jemal A. Global cancer statistics 2018: GLOBOCAN estimates of incidence and mortality worldwide for 36 cancers in 185 countries. CA Cancer J Clin 2018; 68(6): 394-424. [CrossRef]

2. Japanese Gastric Cancer Association. Japanese gastric cancer treatment guidelines 2014 (ver. 4). Gastric Cancer 2017; 20(1): 1-19. [CrossRef]

3. Park DJ, Lee HJ, Kim HH, Yang HK, Lee KU, Choe KJ. Predictors of operative morbidity and mortality in gastric cancer surgery. Br J Surg 2005; 92(9): 1099-102. [CrossRef]

4. Shchepotin IB, Evans SR, Chorny VA, Shabahang M, Buras RR, Nauta RJ. Postoperative complications requiring relaparotomies after 700 gastretomies performed for gastric cancer. Am J Surg 1996; 171(2): 270-3. [CrossRef]

5. Kitano S, Iso Y, Moriyama M, Sugimachi K. Laparoscopy-assisted Billroth I gastrectomy. Surg Laparosc Endosc 1994; 4(2): 146-8. [CrossRef]

6. Okabe H, Tsunoda S, Obama K, Tanaka E, Hisamori S, Shinohara H, et al. feasibility of laparoscopic radical gastrectomy for gastric cancer of clinical stage Il or higher: early outcomes in a phase Il study (KUGC04). Ann Surg Oncol 2016; 23(Supp/ 4): 516-23. [CrossRef]

7. Hu Y, Huang C, Sun Y, Su X, Cao H, Hu J, et al. Morbidity and mortality of laparoscopic versus open $d 2$ distal gastrectomy for advanced gastric cancer: a randomized controlled trial. J Clin Oncol 2016; 34(12): 1350-7. [CrossRef]

8. Shi Y, Xu X, Zhao Y, Qian F, Tang B, Hao Y, et al. Long-term oncologic outcomes of a randomized controlled trial comparing laparoscopic versus open gastrectomy with D2 lymph node dissection for advanced gastric cancer. Surgery 2019; 165(6): 1211-6. [CrossRef]

9. Priego P, Cuadrado M, Ballestero A, Galindo J, Lobo E. Comparison of laparoscopic versus open gastrectomy for treatment of gastric cancer: analysis of a textbook outcome. J Laparoendosc Adv Surg Tech A 2019; 29(4): 458-64. [CrossRef]

10. Ecker BL, Datta J, McMillan MT, Poe SL, Drebin JA, Fraker DL, et al. Minimally invasive gastrectomy for gastric adenocarcinoma in the United States: Utilization and short-term oncologic outcomes. J Surg Oncol 2015; 112(6): 616-21. [CrossRef]

11. Yalcin S. Gastric cancer in Turkey-a bridge between west and East. Gastrointest Cancer Res 2009; 3(1): 29-32. [CrossRef]
12. Clavien PA, Barkun J, de Oliveira ML, Vauthey JN, Dindo D, Schulick RD, et al. The Clavien-Dindo classification of surgical complications: fiveyear experience. Ann Surg 2009; 250(2): 187-96. [CrossRef]

13. Amin MB, Greene FL, Edge SB, Compton CC, Gershenwald JE, Brookland RK, et al. The Eighth Edition AJCC cancer staging manual: continuing to build a bridge from a population-based to a more "personalized" approach to cancer staging. CA Cancer J Clin 2017; 67(2): 93-9. [CrossRef]

14. Kim HG, Park JH, Jeong SH, Lee YJ, Ha WS, Choi SK, et al. Totally laparoscopic distal gastrectomy after learning curve completion: comparison with laparoscopy-assisted distal gastrectomy. J Gastric Cancer 2013; 13(1):26-33. [CrossRef]

15. Jung DH, Son SY, Park YS, Shin DJ, Ahn HS, Ahn SH, et al. The learning curve associated with laparoscopic total gastrectomy. Gastric Cancer 2016;19(1): 264-72. [CrossRef]

16. Cui M, LiZ, Xing J, Yao Z, Liu M, Chen L, et al. A prospective randomized clinical trial comparing D2 dissection in laparoscopic and open gastrectomy for gastric cancer. Med Oncol 2015; 32(10): 241. [CrossRef]

17. Katai H, Mizusawa J, Katayama H, Kunisaki C, Sakuramoto S, Inaki N, et al. Stomach Cancer Study Group of Japan Clinical Oncology Group. Single-arm confirmatory trial of laparoscopy-assisted total or proximal gastrectomy with nodal dissection for clinical stage I gastric cancer: Japan Clinical Oncology Group study JCOG 1401. Gastric Cancer 2019; 22(5): 999-1008. [CrossRef]

18. Chen K, Xu XW, Mou YP, Pan Y, Zhou YC, Zhang RC, et al. Systematic review and meta-analysis of laparoscopic and open gastrectomy for advanced gastric cancer. World J Surg Oncol 2013; 11: 182. [CrossRef]

19. van der Wielen N, Straatman J, Cuesta MA, Daams F, van der Peet DL. Short-term outcomes in minimally invasive versus open gastrectomy: the differences between East and West. A systematic review of the literature. Gastric Cancer 2018; 21(1): 19-30. [CrossRef]

20. Wu CW, Hsiung CA, Lo SS, Hsieh MC, Chen JH, Li AF, et al. Nodal dissection for patients with gastric cancer: a randomised controlled trial. Lancet Oncol 2006; 7(4): 309-15. [CrossRef]

21. Bonenkamp JJ, Songun I, Hermans J, Sasako M, Welvaart K, Plukker JT, et al. Randomised comparison of morbidity after D1 and D2 dissection for gastric cancer in 996 Dutch patients. Lancet 1995; 345(8952): 745-8. [CrossRef]

22. Vural V, Saylam B, Çomçalı B, Düzgün AP, Özer MV, Coşkun F. D1 versus D2 dissection in gastric carcinoma: Evaluation of postoperative mortality and complications. Ulus Cerrahi Derg 2013; 29(1): 1-6. [CrossRef]

23. De Manzoni G, Marrelli D, Baiocchi GL, Morgagni P, Saragoni L, Degiuli $M$, et al. The Italian Research Group for Gastric Cancer (GIRCG) guidelines for gastric cancer staging and treatment: 2015. Gastric Cancer 2017; 20(1):20-30. [CrossRef]

24. Karpeh MS, Leon L, Klimstra D, Brennan MF. Lymph node staging in gastric cancer: is location more important than Number? An analysis of 1,038 patients. Ann Surg 2000; 232(3): 362-71. [CrossRef]

25. Viñuela EF, Gonen M, Brennan MF, Coit DG, Strong VE. Laparoscopic versus open distal gastrectomy for gastric cancer: a meta-analysis of randomized controlled trials and high-quality nonrandomized studies. Ann Surg 2012; 255(3): 446-56. [CrossRef]

26. Mochiki E, Nakabayashi T, Kamimura H, Haga N, Asao T, Kuwano H. Gastrointestinal recovery and outcome after laparoscopy-assisted versus conventional open distal gastrectomy for early gastric cancer. World J Surg 2002; 26(9): 1145-9. [CrossRef] 
27. Angrisani L, Santonicola A, lovino P, Vitiello A, Higa K, Himpens J, et al. IFSO Worldwide Survey 2016: Primary, endoluminal, and revisional procedures. Obes Surg 2018; 28(12): 3783-94. [CrossRef]

28. Umemura A, Koeda K, Sasaki A, Fujiwara H, Kimura Y, Iwaya T, et al. Totally laparoscopic total gastrectomy for gastric cancer: literature review and comparison of the procedure of esophagojejunostomy. Asian J Surg 2015; 38(2): 102-12. [CrossRef]
29. Lee CM, Rao J, Son SY, Ahn SH, Lee JH, Park DJ, et al. Laparoscopic gastrectomy for gastric cancer with simultaneous organ resection. J Laparoendosc Adv Surg Tech A 2013; 23(10): 861-5. [CrossRef]

30. Lee CM, Lee S, Lee D, Park S. How does combined resection affect the clinical outcomes after laparoscopic surgery for serosa-positive gastric cancer?: a retrospective cohort study to Investigate the short-term outcomes of laparoscopic combined resection in patients with $T 4 b$ gastric cancer. Front Oncol 2020; 9: 1564. [CrossRef]

\title{
ORIJINAL ÇALIŞMA-ÖZET
}

\author{
Turk J Surg 2021; 37 (1): 33-40
}

\section{Mide kanserinde açık ve laparoskopik gastrektominin karşılaştırılması: Düşük hasta volümlü merkez deneyimi}

\author{
Adem Yüksel ${ }^{1}$, Murat Coşkun ${ }^{2}$, Hamdi Taner Turgut ${ }^{2}$, Fatih Sümer ${ }^{3}$ \\ 1 Kocaeli Derince Eğitim ve Araştırma Hastanesi, Gastroenterolojik Cerrahi Kliniği, Kocaeli, Türkiye \\ ${ }^{2}$ Kocaeli Derince Eğitim ve Araştırma Hastanesi, Genel Cerrahi Kliniği, Kocaeli, Türkiye \\ ${ }^{3}$ Inönü Üniversitesi Tıp Fakültesi, Gastroenterolojik Cerrahi Anabilim Dalı, Malatya, Türkiye
}

\section{ÖZET}

Giriş ve Amaç: Mide kanseri için laparoskopik gastrektomi, Asya ülkelerinde yaygın olarak yapılmaktadır. Tümör insidansının nispeten düşük ve hasta özelliklerinin farklı olduğu diğer bölgelerde, bu konudaki gelişmeler sınırlıdır. Bu çalışmada, düşük hasta volümlü bir merkezde mide kanseri için açık veya laparoskopik gastrektomi yapılan hastaların erken dönem sonuçlarının karşılaştıııması amaçlandı.

Gereç ve Yöntem: Aynı cerrahi ekip tarafından 2014 - 2019 tarihleri arasında küratif mide rezeksiyonu yapılan hastalara (açık gastrektomi n: 30; laparoskopik gastrektomi n: 30) ait veriler retrospektif olarak inceledik.

Bulgular: Tümör, hastaların \%60 (36/60)' ında proksimal ve orta 1/3 midede lokalizeydi. Laparoskopik gastrektomi grubunda ameliyat süresi istatistiksel anlamlı olarak daha uzundu (median 297,5 vs 180 dakika; $p<0,05$ ). Açık gastrektomi grubunda intraoperatif kan kaybı (median 50 vs 150 ml; $p<0,05$ ) daha fazlaydı. Tüm vakalarda tümör negatif cerrahi sınır sağlandı. Laparoskopik gastrektomide açık cerrahiye göre ortalama çıkarılan lenf nodu sayısı fazla olmasına rağmen gruplar arasındaki fark istatistiksel anlamlı değildi (sırasıyla 28,2 $\pm 11,48$ vs $25,8 \pm 9,78 ; p=0,394$ ). Majör komplikasyon oranı (Clavien-Dindo $\geq$ grade 3) laparoskopik grupta daha azdı (\%6,7 vs \%16,7; $\mathrm{p}=0,642)$. Dört hastada (2 açık grup, 2 laparoskopik grup) mortalite görüldü.

Sonuç: Ileri laparoskopik cerrahi deneyimi olan düşük hacimli merkezlerde, mide kanseri için laparoskopik gastrektomi, açık gastrektomiye benzer morbidite - mortalite riskiyle yapılabilir.

Anahtar Kelimeler: Mide kanseri, laparoskopik gastrektomi, açık gastrektomi, komplikasyon

DOi: 10.47717/turkjsurg.2021.5048 